\title{
Penggunaan (LKS) Eksploratif Berkonteks Budaya Banten Terhadap Kemampuan Pemecahan Masalah Matematis Siswa di SD
}

\author{
${ }^{*}$ Rohimatussa'diyah', Aan Subhan Pamungkas'2, Trian Pamungkas Alamsyah ${ }^{3}$
}

${ }^{123}$ Prodi pendididikan guru sekolah dasar, FKIP, Universitas Sultan Ageng Tirtayasa, Indonesia.

\author{
A R T I C L E I N F O \\ Article history: \\ 1 Maret 2020 Received in \\ revised form \\ 30 Maret 2020 \\ Accepted 11 April 2020 \\ Available online 15 \\ Mei 2020

Kata Kunci:
LKS eksploratif,
budaya Banten,
kemampuan pemecahan
masalah matematis

Keywords:
Explorative worksheets,
Bantenese culture,
mathematic problem solving
ability.

\begin{abstract}
A B S T R A K
Penelitian bertujuan untuk mengetahui kemampuan pemecahan masalah matematis siswa kelas V SD dengan menggunakan LKS eksploratif berkonteks budaya Banten pada materi volume bangun ruang kubus dan balok. Penelitian ini merupakan penelitian kuasi eksperimen dengan menggunakan desain penelitian non-equivalent control group design. Subjek penelitian adalah seluruh siswa kelas $\mathrm{V}$ SDN Banjar Agung 1 sebanyak 46 siswa. Sampel penelitian ini terdiri dari dua kelompok yaitu kelas VA sebagai kelompok eksperimen sebanyak 23 siswa dan kelas VB sebagai kelompok kontrol sebanyak 23 siswa. Treatment dilakukan pada kelompok eksperimen menggunakan LKS eksploratif berkonteks budaya Banten. Hasil penelitian ini menunjukkan bahwa kemampuan pemecahan masalah matematis siswa menjadi lebih baik setelah menggunakan LKS eksploratif berkonteks budaya Banten. Nilai rata-rata yang dicapai kelompok eksperimen 85,93 lebih tinggi dari pada nilai rata-rata kelompok kontrol 74,15. Respon pengguna LKS Eksploratif sebesar 88, $11 \%$ dengan kategori sangat baik. Uji-t dua pihak dengan $\alpha=0,05$ dan
\end{abstract} $\mathrm{dk}=\mathrm{n}_{1}+\mathrm{n}_{2}-2$, diperoleh $\mathrm{t}_{\text {hitung }} 3,03>\mathrm{t}_{\text {tabel }} 2,01$, uji satu pihak didapat bahwa $t_{\text {hitung }} 3,03>\mathrm{t}_{\text {tabel }} 1,68$. Hasil penelitian tersebut menunjukan bahwa terdapat perbedaan kemampuan pemecahan masalah matematis siswa kelompok eksperimen dengan kelompok kontrol dan kemampuan pemecahan masalah matematis siswa kelompok eksperimen lebih baik dari pada kelompok kontrol.

\begin{abstract}
A B S T R A C T
The purpose of this research was to find out the students' ability to solve mathematic problem solving on fifth grade elementary students by using explorative worksheets based on Bantenese culture on the learning material of cubes and blocks volume. This research was quasi-experimental by using non-equivalent control group design. The subject was 46 students on fifth grade in SDN Banjar Agung 1. The sample of this research consisted of two groups. The V/A consisted of 23 students as the experimental group and the V/B consisted of 23 students as a control group. Treatment was carried out in the experimental group by using explorative worksheet with cultural context in Banten. The results of this research indicated that the students' ability on how to solve the mathematic problems would be better after using explorative worksheets based on Bantenese culture. The mean value of experimental group was 85.93 higher than the mean value of the control group, 74.15 . The response of the students who were taught by using explorative worksheet was $88.11 \%$ with a very good category. The two tail of $t$-test with $\alpha=0.05$ and $d f=n 1+n 2-2$, obtained $t_{\text {count }} 3.03>t_{\text {table }} 2.01$, the one tail of $t$-test obtained $t_{\text {count }} 3.03>t_{\text {table }}$ 1.68. The results of this research indicated that there were differences on the students' ability in the mathematic problem solving of the experimental group with the control group and the students' ability in mathematic problem solving of the experimental group was better than the control group.
\end{abstract}

\section{Pendahuluan}


Masyarakat Indonesia pada abad 21 dihadapkan dengan globalisasi yang menyebabkan tantangan besar dalam menghadapi persaingan di semua bidang kehidupan masyarakat. Pendidikan yang dilaksanakan pada abad 21 harus mampu menyiapkan para siswa untuk dapat berkompetensi dengan masyarakat global. Pembelajaran yang di tekankan pada siswa tidak hanya kemampuan dasar membaca, menulis, dan berhitung tetapi siswa dituntut memiliki aspek kreativitas dan inovasi, komunikasi dan kolaborasi, serta berfikir kritis dan mampu memecahkan suatu masalah.

Pemecahan masalah telah menjadi tema utama dalam penelitian dan kurikulum seluruh dunia (Torner, Schoenfeld, \& Reiss, 2007), termasuk di Indonesia.Pemecahan masalah merupakan bagian dari kurikulum matematika yang sangat penting, karena dalam proses pembelajarannya siswa akan memperoleh pengalaman dengan menggunakan pengetahuan serta keterampilan yang telah dimiliki untuk diterapkan pada pemecahan masalah. Menurut Susanto (2014) pemecahan masalah adalah proses menerapkan pengetahuan yang telah dimiliki siswa ke dalam situasi baru. Adapun tahapan pemecahan masalah matematis menurut Polya (Herlambang, 2013) yaitu memahami masalah, merencanakan penyelesaian, menyelesaikan masalah dan melakukan pengecekan kembali. Kemampuan pemecahan masalah memiliki peran penting dalam kemajuan pendidikan karena dalam pemecahan masalah memungkinkan siswa dalam proses pembelajaran memperoleh pengalaman untuk menyelesaikan permasalah menggunakan pengetahuan maupun keterampilan yang telah dimiliki siswa sebelumnya. Secara berbeda Polya (dalam Doorman, dkk., 2007) berpendapat bahwa solving a problem means finding a way out of a difficulty, a way around an obstacle, attaining an aim which was not immediately attainable. Oleh karenanya, dalam memecahkan masalah tentu saja pengetahuan awal atau yang telah diperoleh sebelumnya itu harus sesuai dengan masalah yang dihadapi, karena sebanyak apapun pengetahuan awal yang kita miliki, tidak bisa kita gunakan untuk memecahkan masalah jika tidak sesuai. Kemampuan ini sangat diperlukan siswa, terkait dengan kebutuhan siswa untuk memecahkan masalah yang dihadapinya dalam kehidupan sehari-hari dan mampu mengembangkan diri mereka sendiri (Mulyati, 2011). Melalui kemampuan pemecahan masalah siswa akan memiliki kemampuan dasar yang bermakna dengan pemecahan masalah pola pikir siswa akan berkembang kreatif, logis, sistematis dan berpikir kritis untuk menyelesaikan suatu permasalahan yang dihadapi. Oleh sebab itu, kemampuan pemecahan masalahperlu mendapatkan perhatian khusus dalam proses pembelajaran matematika dari jenjang pendidikan formal paling dasar, yaitu di SD. Pernyataan ini didukung antara lain oleh National Council of Supervisors of Mathematics (NCSM, 1977) bahwa "learning to solve problems is the principal reason for studying mathematics" dan National Council of Teacher of Mathematics (NCTM, 1980) bahwa problem solving must be the focus of the curriculum.

Namun, kemampuan pemecahan masalah matematis di Indonesia masih tergolong sangat rendah, hal tersebut dapat dilihat berdasarkan hasil tes matematika studi TIMSS pada tahun 2015 untuk Sekolah Dasar kelas IV, negara Indonesia berada di posisi ranking 45 dari 50 negara. Sedangkan hasil tes PISA tahun 2018 mengenai matematika, Indonesia pada peringkat 72 dari 78 negara. Salah satu aspek yang dinilai dalam tes PISA yaitu kemampuan pemecahan masalah (Pribadi, 2017). Hasil penelitian yang dilakukan Widodo \& Kartikasari (2017) mengemukakan bahwa rendahnya kemampuan pemecahan masalah matematis dilihat dari hasil uji coba terbatas dengan jumlah 25 siswa diperoleh rata-rata 12,6.

Hal serupa terjadi di sekolah kemampuan pemecahan masalah matematis siswa masih terbilang rendah cenderung belum sesuai dengan yang diharapkan. Hal ini dapat dibuktikan dari 46 siswa SDN Banjar Agung 1 diperoleh hasil pretest rata-rata 46,2 dengan kategori rendah. Faktor rendahnya kemampuan pemecahan masalah matematis siswa yaitu siswa kurang memahami soal yang berbentuk cerita pada soal matematika, dalam menyelesaikan soal siswa kurang mampu menulis prosedur atau rumus yang tepat untuk menyelesaikan masalah secara sistematis sehingga hasilnya masih banyak yang salah. Hasil wawancara yang dilaksanakan pada 11 Januari 2020 dengan guru wali kelas V A SDN Banjar Agung 1, dalam pembelajaran matematika ditemukan permasalah bahwa siswa kurang mampu dalam pemecahan masalah matematis, siswa tidak terbiasa mengerjakan soal matematika dalam penyelesaian soal cerita. Siswa lebih menyukai soal yang berbentuk perhitungan langsung daripada soal cerita yang berbentuk pemecahan masalah matematis.

Berdasarkan pengamatan yang dilakukan pada 13 Januari 2020 saat proses pembelajaran matematika di kelas V SDN Banjar Agung 1 guru masih berperan sepenuhnya pembelajaran dilakukan satu arah guru yang menjelaskan sedangkan siswa hanya diam mendengarkan penjelasan guru, pembelajaran kurang memberikan pengalaman-pengalaman bagi siswa untuk memecahkan suatu permasalahan secara mandiri. Di dalam proses pembelajaran matematika siswa diberi contoh soal beserta cara penyelesainnya tanpa adanya keaktifan siswa dan guru hanya memberikan hafalan-hafalan rumus tanpa siswa bereksplorasi mencari sendiri prosedur penyelesaiannya. 
Pada saat siswa mengerjakan soal yang berbeda dari contoh yang diberikan guru, siswa mengalami kesulitan atau bingung untuk menjawab soal tersebut, padahal siswa hanya perlu mengaitkan soal dengan materi yang telah dipelajari atau materi yang sudah di jelaskan oleh guru. Karena alasan seperti itu siswa beranggapan bahwa matematika pelajaran yang sulit dipahami, pelajaran yang memusingkan dibandingkan dengan pelajaran yang lainnya. Oleh karena itu, pembelajaran matematika harus memiliki daya tarik yang menyenangkan dan tidak membosankan bagi siswa pada saat kegiatan pembelajaran berlangsung. Guru harus melibatkan keaktifan siswa dalam proses pembelajaran sehingga siswa merasa senang dalam belajar dan siswa dapat menyelesaikan atau memecahkan masalah yang dihadapinya secara mandiri. Menurut Heruman (2014) menyatakan bahwa proses pembelajaran matematika di sekolah dasar dapat terjadi revention. Revention atau menemukan suatu cara untuk menyelesaikan permasalahan secara sistematis dalam kegiatan belajar matematika di kelas. Pada kegiatan pembejalaran matematika adanya keterkaitan antara pengalaman yang telah dimiliki siswa dengan materi yang akan diajarkan, sehingga diharapkan proses kegiatan pembelajaran matematika menjadi lebih bermakna tidak hanya belajar mengetahui akan tetapi siswa juga ikut serta berperan aktif dalam pembelajaran.

Hasil penelitian yang dilakukan Widodo \& Kartikasari (2017) menunjukkan bahwa tidak adanya perbedaan yang signifikan terhadap kemampuan pemecahan masalah matematis siswa antara kelas yang menggunakan model creative problem solving (CPS) dengan kelas yang menggunakan model konvensional, dilihat dari hasil uji nonparametrik posttest dengan tingkat kepercayaan $95 \%$, $\mathrm{Z}_{\text {hitung }} 0,641<\mathrm{Z}_{\text {tabel }} 1,96$. Hal demikian dikarenakan kedua kelas tersebut memiliki pemahaman konsep matematika yang rendah.

Salah satu bahan ajar matematika yang dapat menunjang pemecahan masalah matematis siswa adalah dengan LKS eksploratif berkonteks budaya Banten. LKS eksploratif digunakan sebagai bahan ajar yang membantu siswa dalam proses pembelajaran untuk kegiatan bereksplorasi atau kegiatan penyelidikan memecahkan suatu permasalahan. Menurut Trianto (2011) berpendapat bahwa LKS adalah petunjuk yang digunakan siswa untuk melakukan kegiatan penyelidikan atau pemecahan masalah. LKS dikembangkan dalam bentuk penyelidikan sehingga menuntut siswa untuk bereksplorasi. Menurut Karlimah, Rustono, Pranata, \& Lidinillah (2012) kegiatan eksploratif matematika menuntut siswa melakukan sejenis percobaan dengan berbagai cara baik secara formal maupun cara siswa sendiri untuk menemukan jawaban.

LKS eksploratif berkonteks budaya Banten menjadikan siswa lebih banyak belajar mandiri, setiap kegiatan yang terdapat pada LKS eksploratif berkonteks budaya Banten disertai dengan adanya pemahaman yang bermakna sehingga memudahkan siswa dalam pemecahan masalah. LKS eksploratif berkonteks budaya Banten ini sesuai dengan karakteristik, lingkungan hidup siswa dan berdasarkan faktual yang dimilikinya. LKS eksploratif ini diintegrasikan dengan budaya Banten dengan tujuan konteks yang ada pada LKS dekat dengan kehidupan siswa. Sehingga melalui LKS ini selain pemecahan masalah matematis siswa yang akan berkembang, siswa juga akan lebih mengenal kebudayaannya sendiri.

LKS eksploratif berkonteks budaya Banten dianggap layak dan dapat digunakan dalam proses pembelajaran berdasarkan penilaian para ahli diantaranya ahli materi, ahli media, dan ahli bahasa. Berdasarkan penelitian Lestari, dkk. (2019) mengemukakan bahwa pemaham siswa setelah menggunakan LKS Eksploratif berkonteks budaya Banten mencapai sebesar 86,75 dengan kualitas sangat baik. Berdasarkan fakta tersebut peneliti menindaklanjuti ingin mengetahui kemampuan pemecahan masalah matematis siswa setelah menggunakan LKS eksploratif berkonteks Budaya Banten.

Berdasarkan uraian tersebut, maka peneliti mengangkat judul "Penggunaan LKS Eksploratif Berkonteks Budaya Banten Terhadap Kemampuan Pemecahan Masalah Matematis Siswa di SD" dengan tujuan mengetahui perbedaan kemampuan pemecahan masalah matematis siswa yang menggunakan LKS eksploratif berkonteks budaya Banten dengan siswa yang menggunakan LKS biasa, untuk mengetahui pencapaian kemampuan pemecahan masalah matematis siswa yang menggunakan LKS eksploratif berkonteks budaya Banten, dan untuk mengetahui kemampuan pemecahan masalah matematis yang menggunakan LKS eksploratif berkonteks Budaya Banten pada siswa kelas V SD.

\section{Metode}

Metode penelitian yang digunakan dalam penelitian ini adalah metode kuasi eksperimen (Quasi Experimental Design). Adapun desain yang digunakan dalam penelitian ini adalah non-equivalent control group design, pada desain ini ada pretest, perlakuan yang berbeda, dan ada posttest. Dalam penelitian ini menggunakan dua kelompok yaitu kelompok kontrol dan kelompok eksperimen.

Penelitian ini dilakukan selama satu bulan di SDN Banjar Agung 1 Kota Serang, Banten. Populasi penelitian ini adalah seluruh siswa kelas V SDN Banjar Agung 1 sebanyak 46 siswa. Sampel penelitian ini menggunakan teknik purposive sampling. Menurut Sugiyono (2017) purposive sampling adalah penentuan sampel dengan pertimbangan tertentu. Pertimbangan yang diambil dalam menentukan sampel ini adalah 
disesuaikan dengan kebutuhan penelitian penggunaan LKS eksploratif berkonteks budaya Banten. Sampel yang dipilih bagian representatif mewakili karakteristik dari populasi. Kelas VA sebagai kelompok eksperimen sebanyak 23 siswa dan kelas VB sebagai kelompok kontrol sebanyak 23 siswa.

Instrumen yang digunakan dalam penelitian ini adalah tes untuk mengukur kemampuan pemecahan masalah matematis siswa dan angket respon siswa. Tes kemampuan pemecahan masalah matematis diberikan kepada kelas eksperimen dan kelas kontrol yang dilakukan dua kali, sebelum perlakuan (pretest) dan sesudah perlakuan (posttest). Tes berupa soal uraian berjumlah 5 butir yang dibuat berdasarkan indikator kemampuan pemecahan masalah matematis siswa yang terdiri dari memahami masalah, membuat rencana penyelesaian, menyelesaikan soal dan memeriksa kembali hasil yang diperoleh. Angket respon siswa terdiri dari pernyataan positif dan negatif dengan jawaban "Ya" dan "Tidak". Instrumen tes yang digunakan dalam penelitian ini terlebih dahulu dinilai oleh dosen ahli dalam bidang pendidikan matematika sekolah dasar dan diuji coba untuk mengetahui tingkat kelayakan soal dengan uji ketepatan (validitas), keajegan (reliabilitas), indeks kesukaran (IK) dan daya pembeda (DP). Sehingga instrumen yang digunakan pada penelitian ini sudah tervalidasi dan reliabel.

Kriteria pedoman pemberian skor yang digunakan untuk jawaban tes kemampuan pemecahan masalah matematis siswa, dijabarkan dalam tabel 01 di bawah.

Tabel 01. Pedoman Pemberian Skor Jawaban Tes Kemampuan Pemecahan Masalah Matematis

\begin{tabular}{|c|c|c|}
\hline Aspek yang dinilai & Skor & Keterangan \\
\hline \multirow{3}{*}{ Memahami masalah } & 0 & $\begin{array}{l}\text { Salah menginterpretasikan soal atau tidak ada jawaban sama } \\
\text { sekali }\end{array}$ \\
\hline & 1 & $\begin{array}{l}\text { Salah menginterpretasikan sebagian soal atau mengabaikan } \\
\text { kondisi soal. }\end{array}$ \\
\hline & 2 & Memahami masalah atau soal selengkapnya. \\
\hline \multirow{4}{*}{$\begin{array}{l}\text { Perencanaan } \\
\text { penyelesaian }\end{array}$} & 0 & $\begin{array}{l}\text { Menggunakan strategi yang tidak relevan atau tidak ada strategi } \\
\text { sama sekali. }\end{array}$ \\
\hline & 1 & $\begin{array}{l}\text { Menggunakan strategi yang kurang dapat dilaksanakan dan tidak } \\
\text { dapat dilanjutkan. }\end{array}$ \\
\hline & 2 & $\begin{array}{l}\text { Menggunakan strategi yang benar tetapi mengarah pada jawaban } \\
\text { yang salah atau tidak mencoba strategi lain. }\end{array}$ \\
\hline & 3 & Menggunakan prosedur yang mengarah pada solusi yang benar. \\
\hline \multirow{4}{*}{$\begin{array}{l}\text { Pelaksanaan } \\
\text { penyelesaian atau } \\
\text { perhitungan }\end{array}$} & 0 & Tidak ada solusi sama sekali \\
\hline & 1 & Prosedur perhitungan tidak sistematis namun hasil akhir benar. \\
\hline & 2 & $\begin{array}{l}\text { Prosedur sistematis namun hasil salah sebagian, tetapi hanya } \\
\text { karena salah perhitungan saja. }\end{array}$ \\
\hline & 3 & $\begin{array}{l}\text { Prosedur penyelesaian soal dilakukan secara sistematis dan hasil } \\
\text { benar. }\end{array}$ \\
\hline \multirow{3}{*}{ Pemeriksaan kembali } & 0 & Tidak ada pemeriksaan kembali atau tidak ada keterangan apapun. \\
\hline & 1 & Pemeriksaan menghasilkan jawaban yang tidak tepat. \\
\hline & 2 & Pemeriksaan menghasilkan jawaban yang tepat. \\
\hline
\end{tabular}

Data hasil pretest dan posttest diolah dan dianalisis sesuai dengan rumusan masalah yang telah dibuat dengan menggunakan statistik deskriptif dan statistik inferensial. Statistik deskriptif digunakan untuk menganalisis data dengan cara mendeskripsikan atau menggambarkan data yang telah terkumpul. Statistik deskriptif berupa rata-rata, nilai terendah, nilai tertinggi, simpangan baku dan varians. Sedangkan statistik inferensial digunakan untuk menganalisis data dengan membuat generalisasi pada data sampel agar hasilnya dapat diberlakukan pada populasi. Karena data berdistribusi normal dan varians yang homogen maka yang digunakan statistik parametrik.

\section{Hasil dan pembahasan}

Hasil penelitian yang dilakukan selama satu bulan pada kelas V SDN Banjar Agung 1, tahun ajaran 2019/2020 dimulai dari pretest sampai posttest untuk mengetahui kemampuan pemecahan masalah matematis siswa. Pretest dilakukan dengan tujuan untuk mengetahui kemampuan awal pemecahan masalah matematis siswa pada kelas eksperimen dan kelas kontrol. Hasil rata-rata pretest kelas eksperimen dan kelas kontrol dijabarkan dalam tabel 02 berikut ini. 
Tabel 02. Rekapitulasi Data Pretest Kemampuan Pemecahan Masalah Matematis

\begin{tabular}{ccc}
\hline Statistik & \multicolumn{2}{c}{ Pretest } \\
\cline { 2 - 3 } & Kelas Eksperimen & Kelas Kontrol \\
\hline n (banyak siswa) & 22 & 22 \\
Nilai Terendah & 8 & 8 \\
Nilai Tertinggi & 78 & 82 \\
$\bar{x}$ (Rata-Rata) & 48,8 & 46,5 \\
$S$ (Simpangan Baku) & 18,48 & 21,13 \\
$S^{2}$ (Varians) & 341,61 & 446,64 \\
\hline
\end{tabular}

Berdasarkan Tabel 02 di atas, diperoleh nilai rata-rata pretest kelas eksperimen sebesar 48,8 dan kelas kontrol sebesar 46,5. Nilai tertinggi kelas eksperimen $=78$, kelas kontrol $=82$. Nilai terendah kelas eksperimen dan kelas kontrol sama yaitu 8.

Pemberian posttest ini dilakukan dengan tujuan untuk mengetahui pencapaian akhir kemampuan pemecahan masalah matematis yang dimiliki siswa pada kelas eksperimen dan kelas kontrol. Hasil ratarata posttest kelas eksperimen dan kelas kontrol dapat dilihat pada tabel 03 berikut.

Tabel 03. Rekapitulasi Data Posttest Kemampuan Pemecahan Masalah Matematis

\begin{tabular}{ccc}
\hline Statistik & Pretest & Kelas Eksperimen \\
\hline n (banyak siswa) & 23 & Kelas Kontrol \\
Nilai Terendah & 56 & 23 \\
Nilai Tertinggi & 100 & 44 \\
$\bar{x}$ (Rata-Rata) & 85,93 & 100 \\
$S($ Simpangan Baku) & 11,92 & 74,15 \\
$S^{2}$ (Varians) & 142,16 & 15,32 \\
\hline
\end{tabular}

Hasil rekapitulasi data posttest di atas menyatakan bahwa nilai tertinggi kelas eksperimen dan kelas kontrol sama yaitu 100. Nilai terendah kelas eksperimen $=56$ dankelas kontrol $=44$. Kelas eksperimen memperoleh nilai rata-rata sebesar 85,93 lebih tinggi dibandingkan kelas kontrol sebesar 74,15. Diagram rekapitulasi kemampuan pemecahan masalah matematis pretest dan posttest siswa kelas eksperimen dan kelas kontrol ditunjukkan pada gambar 01 berikut.

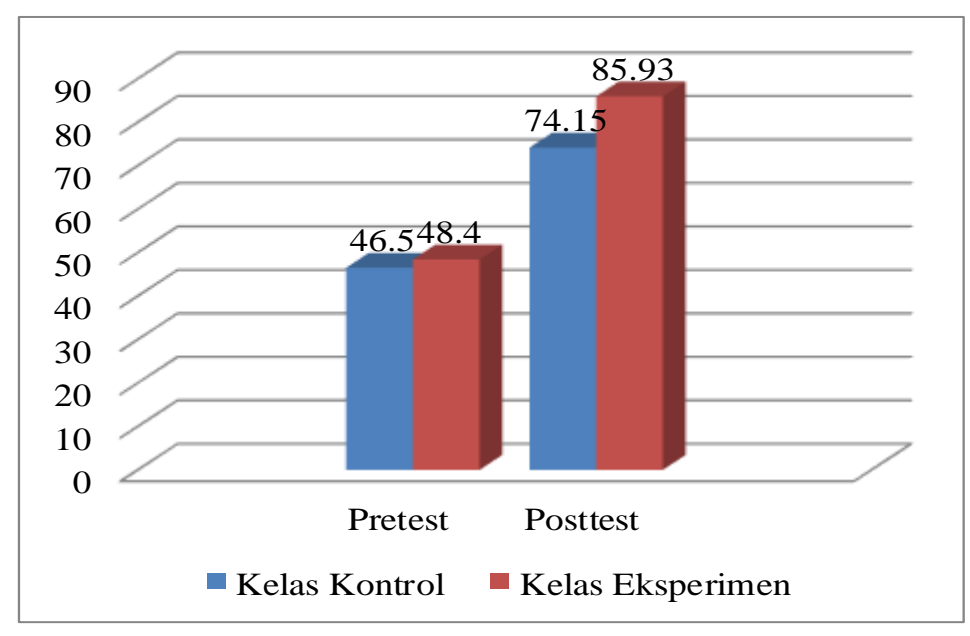

Gambar 01

Rekapitulasi Data Pretest dan Posttest Kelas Eksperimen dan Kelas Kontrol

Penyebab utama terjadinya perbedaan nilai rata-rata kemampuan pemecahan masalah matematis siswa yang semula sama menjadi berbeda yaitu karena berbedanya penerapan LKS maupun model 
pembelajaran di tiap kelompok. Dalam penggunaan LKS eksploratif berkonteks budaya Banten melibatkan siswa secara aktif mulai dari memahami masalah, merencanakan penyelesaian, menyelesaikan masalah hingga memeriksa kembali langkah pemecahan yang siswa gunakan sehingga kemampuan pemecahan masalah matematis siswa terlatih dengan baik dibandingkan dengan LKS biasa yang kurang mengajak siswa untuk aktif melakukan uji coba dan menemukan sendiri materi yang sedang dipelajari.

Kedua kelompok eksperimen dan kelompok kontrol berdistribusi normal dan homogen, maka selanjutnya di uji kesamaan dua rata-rata dengan menggunakan uji-t dua pihak dengan rumus polled varians, $\alpha=0,05$ dengan $\mathrm{dk}=\mathrm{n}_{1}+\mathrm{n}_{2}-2$, dan uji satu pihak (kanan). Hasil analisis uji beda dua rata-rata pretest disajikan dalam tabel 04 di bawah.

Tabel 04. Hasil Uji Beda Dua Rata-rata Pretest

\begin{tabular}{ccc}
\hline Jenis Uji & Statistik & Simpulan \\
\hline Uji-t & $\begin{array}{c}\mathrm{t}_{\text {hitung }}=0,31 \\
\mathrm{t}_{\text {tabel }}=2,01\end{array}$ & Tidak terdapat perbedaan \\
\hline
\end{tabular}

Berdasarkan Tabel 04 di atas didapat bahwa $t_{\text {hitung }}<t_{\text {tabel }}$ yaitu $0,31<2,01$ sehingga dapat disimpulkan bahwa kelas eksperimen dan kelas kontrol pada tes awal berkemampuan sama. Sedangkan asil analisis uji beda dua rata-rata posttest disajikan dalam tabel 05 di bawah.

Tabel 05. Hasil Uji Beda Dua Rata-rata Posttest

\begin{tabular}{ccc}
\hline Jenis Uji & Statistik & Simpulan \\
\hline Uji-t & $\begin{array}{c}t_{\text {hitung }}=3,03 \\
t_{\text {tabel }}=2,01\end{array}$ & Terdapat perbedaan \\
\hline
\end{tabular}

Berdasarkan Tabel $05 \mathrm{di}$ atas didapat bahwa $t_{\text {hitung }}$ 3,03 $>t_{\text {tabel }} 2,01$ sehingga dapat disimpulkan bahwa kelas eksperimen dan kelas kontrol pada tes akhir kemampuan pemecahan masalah matematis yang berbeda setelah diberikan perlakuan. Setelah dilakukan uji beda dua rata-rata posttest, akan dilakukan uji satu pihak posttest yang dijabarkan dalam tabel 06.

Tabel 06. Hasil Uji Satu Pihak Posttest

\begin{tabular}{ccc}
\hline Jenis Uji & Statistik & Simpulan \\
\hline Uji-t & $t_{\text {hitung }}=3,03$ & Kemampuan pemecahan masalah matematis \\
& $t_{\text {tabel }}=1,68$ & kelas eksperimen lebih baik dibanding kelas \\
& & kontrol \\
\hline
\end{tabular}

Pada tabel 06 di atas didapat bahwa $t_{\text {hitung }}>t_{\text {tabel }}$ atau 3,03 $>1,68$ sehingga dapat disimpulkan bahwa kemampuan pemecahan masalah matematis siswa yang menggunakan LKS eksploratif berkonteks budaya Banten lebih baik dari pada siswa yang menggunakan LKS biasa pada tes akhir atau posttest.

Tabel 07. Persentase Posttest Tiap Indikator Kemampuan Pemecahan Masalah Matematis Siswa

\begin{tabular}{|c|c|c|c|c|c|}
\hline \multirow[t]{2}{*}{ No } & \multirow{2}{*}{$\begin{array}{c}\text { Indikator Pemecahan } \\
\text { Masalah }\end{array}$} & \multicolumn{2}{|c|}{ Kelas Eksperimen } & \multicolumn{2}{|c|}{ Kelas Kontrol } \\
\hline & & Persentase & Keterangan & Persentase & Keterangan \\
\hline 1 & Siswa dapat menyebutkan & & & & \\
\hline & $\begin{array}{l}\text { informasi-informasi } \quad \text { yang } \\
\text { diberikan dari pertanyaan yang } \\
\text { diajukan }\end{array}$ & $79,04 \%$ & Sangat Baik & $72,60 \%$ & Sangat Baik \\
\hline 2 & $\begin{array}{l}\text { Siswa dapat menyusun rencana } \\
\text { penyelesaian dengan prosedur } \\
\text { yang sesuai dan dapat } \\
\text { membantunnya } \\
\text { menyelesaikan masalah }\end{array}$ & $90,43 \%$ & Sangat Baik & $76,52 \%$ & Sangat Baik \\
\hline 3 & $\begin{array}{l}\text { Siswa dapat memecahkan } \\
\text { masalah dengan rencana yang } \\
\text { ia gunakan dengan hasil yang }\end{array}$ & $88,98 \%$ & Sangat Baik & $69,56 \%$ & Baik \\
\hline
\end{tabular}




\begin{tabular}{llccccc}
\hline & benar & & & & & \\
Siswa & memeriksa & kembali & & & \\
langkah pemecahan & yang ia & $87,82 \%$ & Sangat Baik & $74,34 \%$ & Baik \\
gunakan
\end{tabular}

Gambaran persentase tiap indikator kemampuan pemecahan masalah matematis siswa kelas eksperimen dan kontrol disajikan pada gambar 02 berikut ini.

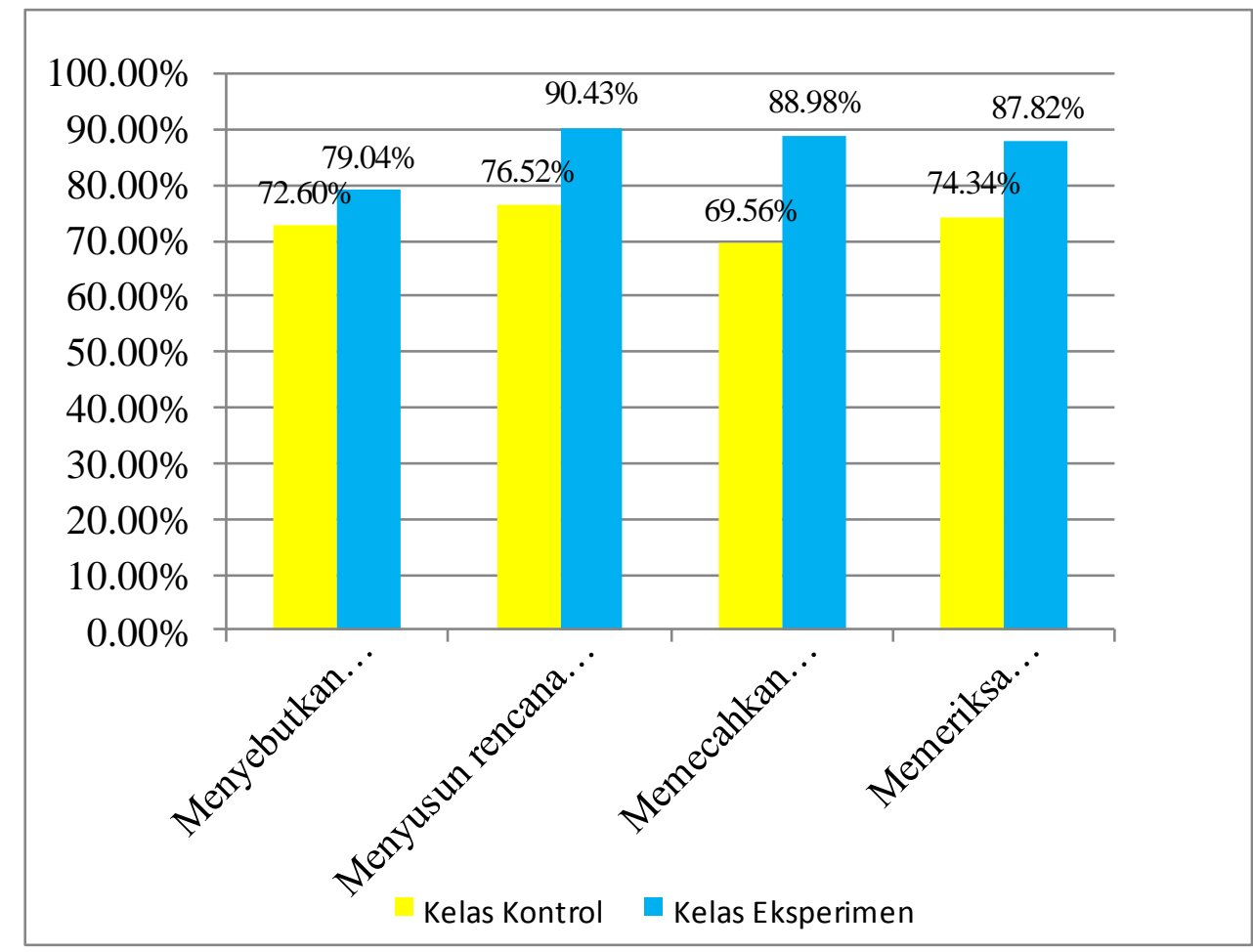

\section{Gambar 02}

Persentase Tiap Indikator Kemampuan Pemecahan Masalah Matematis

Berdasarkan diagram pada gambar 02 di atas secara umum indikator kemampuan pemecahan masalah matematis siswa pada kelas eksperimen lebih tinggi dibandingkan dengan kelas kontrol dari semua indikator. Secara khusus terlihat bahwa persentase indikator tertinggi pada kelas eksperimen terdapat pada indikator nomor 2 yaitu menyusun rencana penyelesaian dengan prosedur yang sesuai, hal serupa terjadi pada kelas kontrol yaitu terdapat pada indikator nomor 2 . Hal tersebut dikarenakan semua siswa mengetahui rumus yang tepat untuk digunakan dalam menyelesaikan masalah sesuai dengan pertanyaan yang diajukan.

Tabel 08. Analisis Data Hasil Respon Siswa

\begin{tabular}{cccc}
\hline Indikator & Skor & Persentase (\%) & Keterangan \\
\hline $\begin{array}{c}\text { Rasa senang terhadap LKS } \\
\text { eksploratif berkonteks budaya } \\
\text { Banten }\end{array}$ & 89 & $96,73 \%$ & Sangat Baik \\
$\begin{array}{c}\text { Motivasi siswa setelah } \\
\text { menggunakan LKS eksploratif } \\
\text { berkonteks budaya Banten } \\
\begin{array}{c}\text { Pemahaman manfaat pelajaran } \\
\text { matematika setelah } \\
\text { menggunakan LKS eksploratif } \\
\text { berkonteks budaya Banten }\end{array}\end{array} \quad 116$ & $84,05 \%$ & Sangat Baik \\
\hline
\end{tabular}


Pada tabel 08 di atas menunjukkan bahwa LKS eksploratif berkonteks budaya Banten menunjukkan responden yang sangat baik. Hal ini dapat dilihat dari indikator rasa senang siswa terhadap LKS eksploratif berkonteks budaya Banten sebesar 96,73\%, motivasi siswa setelah menggunakan LKS eksploratif berkonteks budaya Banten sebesar $84,05 \%$ dan pemahaman manfaat pelajaran matematika setelah menggunakan LKS eksploratif berkonteks budaya Banten sebesar 83,69\% dimana ketiga indikator tersebut masuk dalam "kategori sangat baik".

Berdasarkan hasil perhitungan data yang telah diuraikan sebelumnya, diperoleh nilai rata-rata pretest kelas eksperimen dengan kelas kontrol yang tidak memiliki perbedaan signifikan atau dapat dikatakan bahwasannya kedua kelompok sampel memiliki kemampuan pemecahan masalah yang sama sebelum adanya perlakuan penggunaan LKS yang berbeda. Namun, setelah dilakukan perlakuan di masing-masing kelas yaitu penggunaan LKS eksploratif berkonteks budaya Banten pada kelas eksperimen dan LKS biasa pada kelas kontrol diperoleh nilai rata-rata kemampuan pemecahan masalah matematis yang memiliki perbedaan yaitu kelas eksperimen sebesar 85,93 sedangkan kelas kontrol sebesar 74,15 hal ini bisa terjadi karena terdapat beberapa faktor perbedaan perlakuan yang diberikan pada masingmasing kelompok sampel.

Penyebab utama terjadinya perbedaan nilai rata-rata kemampuan pemecahan masalah matematis siswa yang semula sama menjadi berbeda yaitu karena berbedanya penerapan LKS maupun model pembelajaran di tiap kelompok. Kelompok eksperimen yang menggunakan LKS eksploratif berkonteks budaya Banten tentu saja mendapatkan nilai rata-rata kemampuan pemecahan masalah matematis lebih tinggi dibandingkan dengan siswa kelas kontrol yang menggunakan LKS biasa. Dalam penggunaan LKS eksploratif berkonteks budaya Banten melibatkan siswa secara aktif mulai dari memahami masalah, merencanakan penyelesaian, menyelesaikan masalah hingga memeriksa kembali langkah pemecahan yang siswa gunakan sehingga kemampuan pemecahan masalah matematis siswa terlatih dengan baik dibandingkan dengan LKS biasa yang kurang mengajak siswa untuk aktif melakukan uji coba dan menemukan sendiri materi yang sedang dipelajari. Sejalan dengan pendapat tersebut, Novianti, dkk. (2016) LKS eksploratif merupakan LKS dengan pendekatan eksploratif yang mendukung pelaksanaan kegiatan pembelajaran yang berpusat pada siswa.

Penggunaan LKS eksploratif berkonteks budaya Banten pada kegiatan pembelajaran di kelas eksperimen digunakan secara berkelompok. Kegiatan yang dilakukan siswa ketika proses pembelajaran sesuai dengan kegiatan yang ada pada LKS eksploratif yaitu mengamati, menggali informasi, mencoba, belajar, dan berdiskusi. Kegiatan ini dilakukan agar siswa dapat mengeksplor kemampuan yang ada pada dalam dirinya, menggali lebih dalam hal-hal yang ada di lingkungannya, dan mendiskusikannya dengan teman sekelas untuk menyampaikan hal-hal yang didapatkan bersama teman kelompoknya. Kegiatan ini diawasi dan dibimbing oleh guru sehingga ketika siswa menghadapi kesulitan, siswa dapat bertanya kepada guru. Hal ini dilakukan agar pembelajaran yang didapatkan siswa menjadi lebih bermakna. Rosdiana, dkk. (2016) mengemukakan bahwa pembelajaran yang baik adalah pembelajaran yang bermakna siswa terlibat langsung dalam pembelajaran, adapun salah satu pendekatan yang dapat digunakan adalah pendekatan eksploratif.

Penggunaan LKS eksploratif berkonteks budaya Banten dalam pembelajaran bertujuan untuk mengetahui kemampuan pemecahan masalah matematis siswa pada materi volume bangun ruang kubus dan balok. Berdasarkan hasil yang didapatkan, siswa kelas V A atau kelompok eksperimen terlihat aktif dan bersemangat melaksanakan pembelajaran menggunakan LKS eksploratif berkonteks budaya Banten. Pencapaian akhir dari kegiatan pembelajaran menggunakan LKS eksploratif berkonteks budaya Banten pada kelas eksperimen dan LKS biasa pada kelas kontrol menunjukkan terdapat perbedaan kemampuan pemecahan masalah matematis siswa yang menggunakan LKS eksploratif dengan siswa yang belajar menggunakan LKS biasa. Peningkatan kemampuan pemecahan masalah matematis yang menggunakan LKS eksploratif lebih baik daripada siswa yang belajar menggunakan LKS biasa. Hal ini sesuai dengan pendapat Novianti, dkk. (2016) kegiatan pembelajaran akan menghasilkan sebuah pencapaian yang baik ketika kegiatan tersebut mampu memfasilitasi siswa dan mampu menumbuhkan keaktifan siswa dalam setiap penemuan pengetahuan barunya.

Berdasarkan pembahasan hasil penelitian, maka hipotesis penelitian ini diterima yaitu terdapat perbedaan kemampuan pemecahan masalah matematis siswa yang menggunakan LKS eksploratif berkonteks budaya Banten dengan siswa yang menggunakan LKS biasa dan pencapaian kemampuan pemecahan masalah matematis siswa yang menggunakan LKS eksploratif berkonteks budaya Banten lebih baik daripada siswa menggunakan LKS biasa. 


\section{Simpulan dan saran}

Berdasarkan tujuan penelitian yang telah dirumuskan, maka dapat diambil kesimpulan Nilai ratarata yang dicapai kelompok eksperimen 85,93 lebih tinggi dari pada nilai rata-rata kelompok kontrol 74,15. Respon pengguna LKS Eksploratif sebesar 88, 11\% dengan kategori sangat baik. Kemampuan pemecahan masalah matematis siswa pada kelas yang menggunakan LKS eksploratif berkonteks budaya Banten memperoleh nilai Rata-rata pretest sebesar 48,40 sedangkan posttest 85,93, untuk nilai rata-rata indikator pretest sebesar 49,88\% dengan kategori cukup baik sedangkan nilai rata-rata indikator posttest sebesar $85,07 \%$ dengan kategori sangat baik. Uji-t dua pihak dengan $\alpha=0,05$ dan $d k=n_{1}+n_{2}-2$, diperoleh $t_{\text {hitung }} 3,03>t_{\text {tabel }} 2,01$, uji satu pihak didapat bahwa $t_{\text {hitung }} 3,03>t_{\text {tabel }} 1,68$. Hasil penelitian tersebut menunjukan bahwa terdapat perbedaan kemampuan pemecahan masalah matematis siswa kelompok eksperimen dengan kelompok kontrol dan kemampuan pemecahan masalah matematis siswa kelompok eksperimen lebih baik daripada kelompok kontrol.

Beberapa saran dapat disampaikan melalui penelitian ini diantaranya; 1) Kepada guru diharapkan untuk penelitian lanjutan sebaiknya penggunaan LKS eksploratif berkonteks budaya Banten dapat diuji cobakan pada peserta didik terhadap kemampuan lainnya. 2) Kepada kepala sekolah diharapkan dapat memberikan ruang lebih kepada guru-guru untuk berdiskusi dan mengambangkan kompetensi yang mereka miliki. 3) Kepada peneliti lain diharapkan dapat menggunakan hasil penelitian ini sebagai referensi untuk mengatasi masalah dalam pembelajaran yang dihadapi.

\section{Daftar Rujukan}

Doorman, M., Drijvers, P., Dekker, T., Heuvel-Panhuizen, M., de Lange, J. \& Wijers, M.(2007). Problem solving as a challenge for mathematics education in The Netherlands.ZDM Mathematics Education (2007) 39:405-418.DOI 10.1007/s11858-007-0043-2.

Herlambang. (2013). Analisis Kemampuan Pemecahan Masalah Matematika Siswa Kelas VII-A SMP Negeri 1 Kepahiang tentang Bangun Datar Ditinjau dari Teori Van Hiele. Universitas Bengkulu.

Heruman. (2014). Model Pembelajaran Matematika di Sekolah Dasar. Bandung: Remaja Rosdakarya.

Karlimah, Rustono, Pranata, O. H., \& Lidinillah, D. A. M. (2012). Pengembangan Kemampuan Proses Matematika Siswa Melalui Pembelajaran Matematika Dengan Pendekatan Tidak Langsung Di Sekolah Dasar. Jurnal Pendidikan MIPA, 13(2), 105-111.

Lestari, H., dkk. (2019). Pengembangan Lembar Kerja Siswa Eksploratif Berkonteks Budaya Banten pada Mata Pelajaran Matematika di Sekolah Dasar. Jurnal Pengkajian Ilmu Dan Pembelajaran Matematika Dan IPA IKIP Mataram, 7(1), 48-59.

Mulyati, Tita. (2011). Kemampuan Pemecahan Masalah Matematis Siswa Sekolah Dasar. Jurnal Pendidikan Dasar, 3(2). DOI: https://doi.org/10.17509/eh.v3i2.2807

National Council of Supervisors of Mathematics (NCSM) (1977)

Novianti, E., dkk. (2016). Pendekatan Eksploratif untuk Meningkatkan Kemampuan Pemecahan Masalah Matematis dan Motivasi Belajar Siswa. Jurnal Pena Ilmiah, 1(1), 401-410.

Pribadi, A. (2017). Pengembangan Soal Penalaran Model TIMSS pada Materi Geometri dan Pengukuran SMP. Jurnal Pendidikan Matematika, 1(2), 115-128.

Rosdiana, D., dkk. (2016). Pendekatan Eksploratif untuk meningkatkan Kemampuan Berpikir Kreatif dan Disposisi Matematis. Jurnal Pena Ilmiah, 1(1), 231-240.

Sugiyono. (2017). Metode Penelitian Kuantitatif, Kualitatif, dan R\&D. Bandung: Alfabeta.

Susanto, A. (2014). Teori Belajar dan Pembelajaran di Sekolah Dasar. Jakarta: Kencana Prenada Media Group.

Torner, Schoenfeld, \& Reiss (2007). Problem solving in the mathematics classroom: the German perspective. ZDM Mathematics Education (2007) 39:431-441.DOI 10.1007/s11858-007-0040-5.

Trianto. (2011). Model Pembelajaran Terpadu. Jakarta: Bumi Aksara.

Widodo, S., \& Kartikasari. (2017). Pembelajaran Pemecahan Masalah Matematis Siswa Sekolah Dasar Dengan Model Creative Problem Solving (CPS). Jurnal PRISMA Universitas Suryakancana Pembelajaran, VI(1), 57-65. 